\title{
Penerapan AAUPPL oleh Administrasi (Suatu Upaya Menuju “Clean and Stable Government”)
}

\author{
Jazim Hamidi \\ Universitas Brawijaya Malang
}

\begin{abstract}
Administrative judges can apply the AAPPL to examine validity of administrative decisions of state by means of connecting relevance substantive legal norms through deductive reasoning. There are two standards to qualify as to whether an administrative decision is in contradiction with the AAUPPL: written legal norms and unwritten legal norms in form of the AAUPPL. The AAUPPL is an effective means of control to examine administrative policies or decisions that are not touched upon by written laws, and, hence will reduce state policies and decisions that are legally immune.
\end{abstract}

Keywords: administrative decisions, judges, control, validity.

$\mathrm{M}$ enggagas masalah penerapan Asasasas Umum Penyelenggaraan Pemerintahan Yang Layak/AAUPPL ("Algemene Beginselen van Behoorlijk Bestuur/ABBB") di Indonesia, tidak dapat dipisahkan dengan sejarah munculnya suatu konsep yang diajukan oleh Commisie de La Monchy di Parlemen Belanda tahun 1950. Konsep itu berisi tentang gagasan peningkatan perlindungan hukum (verhoogde rechtsherming) bagi rakyat dari tindakan Administrasi Negara yang dipandang merugikan. Komisi ini berpendapat, upaya perlindungan hukum harus didasarkan kepada asas hukum (pemerintahan) yang hidup di masyarakat, artinya asas hukum yang lahir dari kebutuhan hukum bagi para warga dalam upaya melindungi diri mereka dari tindakan Administrasi Negara yang tidak sewenangwenang.
Konsep tersebut kemudian dikembangkan oleh Van der Grinten pada tahun 1959, melalui suatu laporan tentang penyelesaian sengketa Administrasi di lingkungan Peradilan Administrasi. (Kuncoro, 1985 : 28 -29).

Meskipun beberapa usul dan pendapat yang diajukan oleh Komisi de la Monchy dan Van der Grinten di atas tidak seluruhnya diterima, tetapi istilah "AAUPPL/ABBB" tersebut secara bertahap mulai diterapkan oleh Hakim Administrasi untuk menguji keputusan (beschikking) Administrasi Negara. Kebiasaan penerapan AAUPPL melalui sarana yurisprudensi ini, akhirnya diikuti oleh para Pembentuk Undangundang dengan memasukkan asas tersebut ke dalam beberapa peraturan perundangundangan, antara lain pada pasal 8 ayat (1d) Wet AROB tahun 1978. (Steenbeek dan Stroenk, 1998, 223). 
UNISIA, Vol. XXX No. 66 Desember 2007

Pada mulanya, para pejabat Administrasi Negara di Belanda khawatir kalau-kalau AAUPPL dijadikan sarana kontrol oleh Hakim Administrasi untuk menguji kebijakan (beleid) politiknya. Kekhawatiran semacam itu, barangkali sekarang sudah tidak relevan lagi, karena Administrasi Negara dalam menjalankan layanan umum (service public) dilekati dengan asas "Nach freies Ermessen" dan asas "beoordeling vrijheid".

Meskipun demikian, kebebasan bertindak tersebut tidak dapat digunakan dengan sebebas-besanya, karena segala tindakan Administrasi Negara dibatasi oleh "tujuan" diberikannya wewenang dan tidak boleh bertentangan dengan hukum (baik tertulis maupun tidak tertulis, termasuk dengan AAUPPL).

Urgensi keberadaan AAUPPL, di samping sebagai "pedoman" bagi Administrasi Negara, ia merupakan "alat uji" yang dapat digunakan oleh Hakim Adminitrasi. Dengan demikian, penerapan AAUPPL merupakan salah satu syarat untuk mewujudkan pemerintahan yang bersih dan berwibawa (clean and stable geovernemen). (Sjachran, 1992 : 8).

Secara moral, sikap "bersih" dapat menumbuhkan daya tarik yang simpatik bagi bawahannya untuk turut berpartisipasi aktif, sebaliknya sifat kotor dapat menimbulkan perilaku distruktif dan penilaian negatif lainnya. Adapun sikap "berwibawa"bagi suatu pemerintahan, tidak cukup hanya dengan pendekatan kekuasaan yang cenderung legalistik formal, melainkan harus dengan perilaku keteladanan para pemimpinnya (Syafrudin, 1982: 15). Jadi esensi pemerintahan yang bersih dan berwibawa, adalah pemerintahan yang mampu menampilkan budaya kerja kreatif dan inovatif, perilaku keteladanan, serta menjunjung tinggi demokratisasi.
Catatan sejarah sulit dibantah bahwa praktik penyelenggaraan Peradilan Administrasi di Belanda (khususnya mengenai penerapan AAUPPL) mempunyai pengaruh cukup besar bagi perkembangan Peradilan Administrasi di Indonesia. Terbukti sebelum Lembaga Peradilan Administrasi terbentuk, sengketa administrasi negara diselesaikan melalui Peradilan Umum (Bagian Perdata). ${ }^{2}$ Setelah UU No. 5 tahun 1988 tentang "Peradilan Administrasi" diundangkan 29 Desember 1986 dan efektif berjalan sejak 14 Januari 1991, kompetensi penyelesaian sengketa administrasi negara beralih kepada Peradilan Administrasi. Adapun mengenai kemungkinan dapat diterapkannya AAUPPL sebagai alat uji dari segi hukum (rechtmatigheidstoetsing), secara implisit dapat dicantolkan ke dalam pasal 53 ayat (2) UU No. 5 tahun 1986.

Permasalahan yang muncul, dapatkah Hakim Administrasi menerapkan AAUPPL sebagai "alat uji" terhadap keabsahan Keputusan Administrasi Negara? Dan bagaimana Hakim Administrasi dapat mengkualifisir bahwa Keputusan Adminisrasi Negara itu terbukti bertentangan dengan beberapa AAUPPL? Masalah-

1 Nach Freies Ermessen adalah kebebasan bagi Administrasi Negara untuk mengambil suatu keputusan/kebijakan berdasarkan pendapatnya yang wajar, apabila terdapat kekurangjelasan dalam sumber hukum yang tertulis. Adapun beoordeling vrijheid adalah kebebasan bagi Administrasi Negara untuk mengambil suatu kebijakan/ tindakan berdasarkan pendapatnya yang wajar, apabila sama sekali belum ada peraturan hukum yang mengaturnya.

${ }^{2}$ Beberapa contoh Putusan Mahkamah Agung yang berkenaan dengan sengketa Administrasi Negara, dapat diperiksa ke dalam Sjahran Basah, Eksistensi dan Tolok Ukur Badan Peradilan Administrasi di Indonesia, cet. Kedua, Alumni, Bandung, 1989, hlm. $240-252$. 
Penerapan AAUPPL Oleh Hakim Administrasi (Suatu Upaya ...); Jazim Hamidi

masalah inilah yang hendak dikaji dalam pembahasan berikut.

\section{AAUPPL, dalam Lintasan Sejarah di Indonesia}

Momentum sidang Konstituante 1956 - 1959, merupakan tonggak sejarah bagi pertumbuhan AAUPPLdi Indonesia. Penulis katakan "tonggak sejarah", karena pada waktu itu AAUPPL dijadikan sebagai salah satu konsep dasar menuju terselenggaranya "pemerintahan yang konstitusional". Di samping itu, AAUPPL telah menjadi landasan etik bagi pergaulan antar negaranegara merdeka yang menjunjung tinggi nilai-nilai kepatutan dan keadilan. (Adnan, 1956-1959:6)

Pemikiran dan pembahasan mengenai AAUPPL menjadi lebih populer setelah disajikan oleh Kuntjoro Purbopranoto dalam bukunya berjudul "Beberapa Catatan Hukum Tata Pemerintahan dan Peradilan Administrasi Negara". Apa yang dikemukakan oleh Kuntjoro ini sebagian besar berasal dari rangkuman kuliah Crince Le Roy pada penataran lanjutan Hukum Tata Negara dan Hukum Tata Pemerintahan pada Fakultas Hukum UNAIR Surabaya Tahun 1976.(Kuncoro, 1985 : 30)

Konsep AAUPPL yang dimaksud, terdiri dari 13 (tiga belas) butir asas yaitu: asas kepastian hukum, asas keseimbangan, asas kesamaan, asas kecermatan, asas motivasi pada setiap keputusan, asas tidak menyalahgunakan wewenang, asas permianan yang jujur, asas keadilan, asas menanggapi harapan yang wajar, asas peniadaan akibat keputusan yang batal, asas perlindungan atas pandangan dan cara hidup pribadi, asas kebijaksanaan, dan asas penyelenggaraan kepentingan umum.

Lebih lanjut Kuntjoro Purbopranoto menegaskan, khusus untuk penyelenggaraan pemerintahan di Indonesia asas-asas tersebut harus disesuaikan dengan pokok-pokok Pancasila dan UUD 1945. Pernyatan senada dikemukakan oleh Sjachran Basah, apabila AAUPPL hendak dijadikan batu ujian bagi Hakim Administrasi harus terlebih dahulu diseleksi dan disesuaikan dengan nilai-nilai yang terkandung dalam Pancasila dan UUD 1945, sehingga akan ditemukan visi tentang AAUPPL yang sesuai dengan nilai-nilai budaya Indonesia (Sjachran, 1992 : 9)

Ranah argumentasi kedua ahli hukum di atas dapat difahami, karena AAUPPL yang konon berasal dari Belanda itu belum tentu semuanya sesuai dengan budaya Indonesia. Karena itu perlu dilakukan penggalian dan penelitian mengenai AAUPPL versi Indonesia, dengan Pancasila dan UUD 1945 sebagai filternya.

Melihat kenyataan yang ada, sebetulnya Pemerintah sudah berulang kali memprakarsai normatifisasi AAUPPL ke dalam suatu Undang-undang seperti Wet AROB di Belanda. Namun upaya tersebut baru terealisir secara formal setelah diundangkannya UU No. 5 tahun 1986. Itupun belum dicantumkan secara tegs ke dalam salah satu pasalnya, kecuali baru sebagian asas dari AAUPPL yaitu "asas larangan penyalahgunaan wewenang" (detournement de pouvoir) dan "asas larangan tidak sewenang-wenang" (willekeur).

Ketentuan pasal dimaksud, sebagaimana yang dimuat dalam pasal 53 ayat (2) butir b dan c, yaitu:

"Alasan-alasan yang dapat digunakan dalam gugatan sebagaimana dimaksud dalam ayat (1) adalah:

a. Keputusan Administrasi Negara yang digugat itu bertentangan dengan peraturan perundang-undangan yang berlaku. 
UNISIA, Vol. XXX No. 66 Desember 2007

b. Badan atau Pejabat Administrasi Negara pada waktu mengeluarkan keputusan sebagaimana dimaksud dalam ayat (1) telah menggunakan wewenangnya untuk tujuan lain dari maksud diberikannya wewenang tersebut.

c. Badan atau Pejabat Administrasi Negara pada waktu mengeluarkan keputusan sebagaimana dimaksud dalam ayat (1) setelah mempertimbangkan semua kepentingan yang tersangkut dengan keputusan itu seharusnya tidak sampai pada pengambilan atau tidak pengambilan keputusan tersebut (Kursif, penulis)

Satu tahun setelah diberlakukannya UU No. 5 tahun 1986 tepatnya tanggal 14 Januari 1991, Pemerintah (cq. Mahkamah Agung) telah mengeluarkan JUKLAK No. 052/Td.TU/III/1992 (Bagian V butir 1), mengenai petunjuk teknis penerapan AAUPPL oleh Hakim Administrasi melalui putusan-putusannya. Walaupun secara teoritis, kehadiran petunjuk pelaksanaan ini sempat mengundang polemik di kalangan para ilmuwan hukum.

\section{Hampiran Teoretik Penerapan AAUPPL}

Menurut Friederich Julius Sthal, di antara ciri utama negara hukum adalah pemerintah dalam melaksanakan tugas dan kewajibannya berdasar atas hukum atau peraturan perundang-undangan, dan adanya mekanisme kontrol oleh lembaga-lembaga, dan adanya mekanisme kontrol oleh lembaga-lembaga peradilan yang mandiri (Peradilan Administrasi, kursif Penulis). (Sumantri, 1992: 10).

Berangkat dari pendapat di atas, paling tidak ada dua kerangka teoretik dasar yang dapat diangkat untuk menstimulir pembahasan selanjutnya.

Pertama, bahwa pemerintah dalam menjalankan tugas "service public" harus mendasarkan kebijakannya di atas hukum (tertuis maupun tidak tertulis). Dalam aliran filsafat positivisme hukum, hukum merupakan perintah penguasa yang berdaulat dan hukum merupakan kehendak dari negara. Jadi kebijakan penguasa bersenyawa dalam hukum.

John Austin dalam teorinya "Analitical Jurisprudence" atau sering disebut teori "hukum yang analistis", membagi hukum dalam dua bentuk yaitu "positive law" (peraturan tertulis/undang-undang) dan "positive morality" (hukum tidak tertulis/ hukum kebiasaan). Logika hukumnya adalah peraturan perundang-undangan dan hukum kebiasaan diakui sebagai hukum, apbaila telah dilakukan oleh penguasa yang berwenang. Di samping itu menurut Hans Kelsen dalam salah satu teorinya menyatakan, hukum itu bersifat hirarkis artinya ketentuan yang paling bawah tidak boleh bertentangan dengan ketentuan yang lebih atas derajadnya (teori stufenbau des rechti) (Salman, 1986: 13-14).

Hemat penulis, esensi dari kedua pandangan di atas bahwa setiap kebijakan yang dibuat oleh Administrasi Negara seyogyanya disamping memperhatikan aspek legalitas, juga harus memperhatikan aspek hirarkhis hukum, dan hukum kebiasaan atau aspek moralitas yang bersendikan keadilan. Pada aspek yang terakhir inilah, AAUPPL berfungsi sebagai salah satu dasar pertimbangan bagi Administrasi Negara dalam mengeluarkan kebijakannya, sebab bila tidak, akan menjadi "senjata makan tuan". Artinya kebijakan yang menafikan AAUPPL, justru AAUPPL 
Penerapan AAUPPL Oleh Hakim Administrasi (Suatu Upaya ...); Jazim Hamidi

berbalik menjadi alat uji untuk membatalkan kebijakan tersebut. $^{3}$

Kedua, salah satu cermin dari negara hukum adalah adanya Peradilan Administrasi. la mempunyai peran sebagai lembaga pengawas (judicial control) terhadap sikap tindak Administrasi Negara. Di pihak lain, ia sebagai sarana untuk melindungi hak-hak individu dan warga masyarakat dari tindakan penyalahgunaan wewenang pemerintah.

Sebagai lembaga kontrol, ciri-ciri yang melekat pada Peradilan Administrasi adalah: (Paulus, 1993: xviii)

1. Pengawasan yang dilakukan bersifat " $e x$ ternal control", karena ia merupakan lembaga yang berada di luar kekuasaan Administrasi Negara (bestuur).

2. Pengawasan yang dilakukan lebih menekankan pada tindakan represif atau lazim disebut "control a posteriori", karena selalu dilakukan sesudah terjadinya perbuatan yang dikontrol.

3. Pengawasan itu bertitik tolak pada segi "legalitas", karena hanya menilai dari segi hukum (rechtmatig)-nya saja.

Fungsi pengawasan Peradilan Adminsitrasi memang sulit dilepaskan dengan fungsi perlindungan hukum bagi masyarakat (individu-individu), sebab seolah-olah posisi individu di depan Pengadilan berada pada pihak yang lebih lemah.

Pada sisi lain, prinsipnya hakim tidak diperkenankan menguji beleid (kebijakan) pemerintah, karena beleid itu didasarkan pada asas nach freies ermessen dan beoordeling vrijheid dalam rangka menjalankan tugas-tugas publik. Walaupun demikian, penyelenggaraan kedua asas tersebut tidak boleh bertentangan dengan norma-norma hukum, dan nilai kepatutan yang hidup dalam masyarakat. Adanya pembatasan kebebasan sikap-tindak
Administrasi Negara inilah, yang dapat mengarah kepada sikap kehati-hatian dan bertanggung jawab.

Menurut Sjachran Basah dalam teorinya yang sering dikenal dengan teori "batas'atas" dan "batas-bawah" menandaskan, walaupun Administrasi Negara memiliki keleluasaan dalam menentukan kebijakankebijakan, tetapi sikap-tindaknya haruslah dapat dipertanggungjawabkan secara moral maupun secara hukum. Pertanggungjawaban secara moral itu kepada Tuhan Yang Maha Esa, dan secara hukum itu harus memperhatikan batas atas (UUD 1945 jo, TAP MPRS No. XX/MPRS/ 1966 serta TAP MPR No. V/MPR/1973) dan batas bawah (UUD 1945 jo. TAP MPR No. II/MPR/1983) pada Bidang Hukum butir 3.e dan pasal 27 ayat (2) UUD 1945 sebagai kunci tolok ukurnya) (Sjachran, 1992: 9).

Terhadap kebijakan Administrasi Negara yang bertentangan dengan hukum dan asas kepatuhan, maka beleid semacam itu dapat diuji melalui mekanisme judisial review dan pengujian oleh Hakim Administrasi.

Mekanisme judisial review, dilakukan terhadap kebijakan yang sifatnya pengaturan secara umum. Adapun mekanisme pengujian oleh Hakim Administrasi, dilakukan terhadap kebijakan dalam bentuk penetapan tertulis (beschikking) yang memenuhi unsur-unsur individual, konkret, dan vinal, serta merugikan seseorang dan/ atau badan hukum perdata. Bentuk pengujian yang kedua inilah yang menjadi

3 Hemat Penulis, kebijakan produk Administrasi Negara dapat berupa: Peraturan Perundang-undangan, Peraturan kebijakan (beleidsregel), norma Konkret, Rencanarencana, Keputusan/ Penetapan (beschikking). Tapi dalam konteks tulisan ini "kebijakan" yang dimaksud dibatasi pada beschikking. 
pembahasan dalam tulisan ini. Tetapi perlu diingat, tidak semua beschikking dapat diuji dengan alat uji berupa AAUPPL, melainkan hanya terhadap keputusan yang berbentuk "vrij beschikking" (penetapan bebas).

\section{AAUPPL: Asas Hukum dan/atau Norma Hukum}

Sub tema ini muncul karena dilatarbelakangi oleh suatu pendapat umum, bahwa asas hukum itu bukan norma hukum. Hakim tidak akan dapat menerapkan asas hukum secara langsung ke dalam kasus konkret, sebelum asas itu dikonkretkan terlebih dahulu. Persoalannya, AAUPPL itu asas hukum atau norma hukum.

Secara makro atau filsafati, Moh. Koenoe mendefinisikan "asas" sebagai bentuk awal pancaran normatif dari suatu filsafat hidup, ia sebagai suatu instruksi untuk bagaimana memandang dan menangani suatu lingkup persoalan kehidupan. Bilamana lingkup persoalan itu persoalan hukum, maka asas itu disebut "asas hukum. (Koesnoe, 1995: Wawancara) Sedangkan menurut Bachsan Mustafa, "Norma (hukum)" adalah ketentuanketentuan tentang bagaimana seharusnya manusia bertingkah laku dalam pergaulan hidup dengan sesamanya (Mustafa, 1990: 54).

Dalam pemahaman hukum secara elementer, Ateng Syafrudin menyederhanakan pemahaman antara asas (hukum) dengan norma (hukum) tersebut sebagai berikut (Syafrudin, 1994: 64):

Asas merupakan:

- Dasar pemikiran yang umum dan abstrak

- Ide atau konsep

- Tidak mempunyai sanksi

Norma merupakan:

- Aturan yang konkret
- Penjabaran dari ide

- Mempunyai sanksi

Dari pendapat para ahli hukum di atas, dapat disimpulkan, "asas hukum" merupakan abstraksi dari norma-norma hukum, sedangkan "norma hukum" merupakan konkretisasi dari asas-asas hukum dalam bentuk peraturan hukum konkret.

Selanjutnya, bagaimanakah hubungan antara asas hukum dalam norma hukum? Dan apakah AAUPPL itu asas hukum atau norma hukum?

Paul Scholten berpendapat, asas hukum (rechtsbeginsel) bukanlah sebuah aturan hukum (rechtsregel). Untuk dapat dikatakan sebagai aturan hukum, asas hukum adalah terlalu umum, sehingga ia tidak akan mengatakan apa-apa atau tidak berbicara terlalu banyak (of niets of veel to veel zeide). Penerapan asas hukum secara langsung melalui jalan subsumsi atau pengelompokan sebagai aturan tidaklah mungkin, untuk itu terlebih dahulu perlu dibentuk isi yang konkret. Dengan perkataan lain, asas hukum bukanlah hukum, namun hukum tidak akan dapat dimengerti tanpa asas-asas tersebut. Kembali Paul Scholten menegaskan, adalah menjadi tugas ilmu pengetahuan hukum untuk menelusuri dan mencari asas hukum itu dalam hukum positif (scholten, 1993: 86).

Berkaitan dengan pernyataan di atas, A. Hamid S. Attamimi memberikan jawaban sekaligus tanggapannya, bahwa norma hukum berbeda dengan asas hukum pada sifatnya yang mengatur. Dalam pembentukan norma hukum yang berbeda pada suatu sistem norma hukum yang utuh, fungsi asas hukum (meski tidak hilang sama sekali) menjadi "terdesak" ke belakang oleh norma hukum. Lain halnya pada pembentukan norma hukum yang 
Penerapan AAUPPL Oleh Hakim Administrasi (Suatu Upaya ...); Jazim Hamidi

berada dalam lingkup kebijaksanaan yang tidak terikat atau bebas, di sana asas hukum menjadi "penting" dalam memberikan bimbingan dan pedoman pada pembentukan norma hukum tersebut (Attamimi, 1990: 302 $-303)$.

Berangkat dari uraian di atas, hemat penulis sebagian dari AAUPPL masih dalam bentuk aslinya yaitu sebagai asas hukum, ia hidup dan berkembang dalam pergaulan masyarakat. Sebagian yang lain, AAUPPL dapat diturunkan dari norma hukum (baik yang tersurat maupun yang tersirat), atau sudah ternormatifisir dalam hukum positif berupa pasal-pasal.

\section{Penerapan AAUPPL dalam Kasus Konkret}

Menurut Philipus M. Hadjon, proses penerapan asas hukum (termasuk AAUPPL, kursif penulis) secara teknis operasional dapat didekati dengan dua cara yaitu melalui penalaran hukum induksi dan deduksi (Philipus, 1994: 12-15).

Pengalaman praktik menunjukkan bahwa penyelesaian sengketa di Pengadilan selama ini biasanya diawali dengan langkah induksi, yaitu berupa merumuskan faktafakta, mencari hubungan sebab-akibat, dan mereka-reka probabiitasnya. Setelah langkah induksi, diikuti dengan upaya penerapan hukum sebagai langkah deduksi. Dalam penerapan hukum, selalu diawali dengan identifikasi atauran hukum. Upaya mengidentifikasi aturan hukum, seringkali menjumpai keadaan-keadaan; kekosongan hukum (leemten in het recht), antinomi hukum (konflik antar norma hukum), dan norma hukum yang kabur (vage normen).

Dalam menghadapi kondisi kekosongan hukum (peraturan perundangundangan), hakim berpegang pada asas "ius curia novit" yaitu hakim dianggap tahu hukum dan tidak boleh menolak perkara karena alasan aturannya tidak jelas (tidak ada). Disamping itu, hakim wajib menggali nilai-nilai hukum yang hidup dalam masyarakat (diantaranya, AAUPPL). ${ }^{4}$ Upaya ini sering disebut dengan rechtsvinding (metode penemuan hukum). ${ }^{5}$

Pada saat menghadapi antinomi hukum (konflik antar norma hukum), maka berlakulah asas-asas penyelesaian konflik yaitu: asas lex posterior derogat legi priori, asas lex specialis derogat legi generali, dan asas lex superior derogat legi inferior. Persoalan yang muncul pada saat menerapkan ketiga asas di atas adalah: adakah hukum positif yang mengatur tentang asas itu, apakah ada ketentuan hukum positif yang justru melemahkan asas itu, dan apakah suatu aturan hukum itu batal demi hukum apabila asas tersebut diterapkan. P.W. Brouwer memberikan petunjuk praktis untuk menyelesaikan konflik tersebut, diantaranya dengan pengingkaran (disavowal), penafsiran kembali (reinterpretation), dan pembatalan (invalidation). (Philipus, 1994: 14).

Dalam hal menghadapi norma hukum yang kabur, langkah pertamanya berpegang pada rasio hukum (melakukan konstruksi hukum) atas norma hukum yang masih kabur itu, kemudian hakim dapat menetapkan metode interpretasi mana yang dianggap paling tepat. Atau hakim dapat juga menjadikan ketentuan undang-undang tersebut hanya sebagai sarana untuk membantu menemukan pemecahan masalah ke dalam peristiwa konkret. Oleh Sudikno Mertokusumo, metode penemuan

\footnotetext{
${ }^{4}$ Periksa pasal 14 ayat (1) dan Pasal 27
} ayat (1) UU No. 14 tahun 1970.

${ }^{5}$ Ada dua metode penemuan hukum, yaitu interpretasi undang-undang dan konstruksi hukum. 
hukum yang tidak terikat erat pada ketentuan undang-undang ini disebut metode "penemuan hukum bebas" (Sudikno, 1993: 29).

Setelah mencermati gagasan di atas, ditemukan bentuk/model "proses penerapan AAUPPL" di pengadilan dalam tiga tahap: tahap pengumpulan fakta (dalam hukum acara perdata disebut tahap mengkonstatir), tahpa mengidentifikasi hukum (tahap mengkualifisir), dan tahap merumuskan AAUPPL (tahap mengkonstituir).

Berdasarkan hasil penelitian yang penulis lakukan di PTUN Bandung, PT. TUN Jakarta, dan di Mahkamah Agung RI, untuk kurun waktu 1991 - 1995 diperoleh data Putusan-putusan Hakim yang menerapkan AAUPPL sebagai berikut: di PTUN Bandung ditemukan 5 Putusan yang menerapkan AAUPPL dari 131 Putusan; di PT. TUN Jakarta ditemukan 9 Putusan yang menerapkan AAUPPL dari 253 Putusan; dan di Mahkamah Agung RI ditemukan 15 putusan yang menerapkan AAUPPL dari 322 putusan.

Berikut ini penuis menukilkan satu Putusan Mahkamah Agung bernomor : 10K/ TUN/1992 tertanggal 15 Oktober 1994, sebagai sampel/contoh Putusan yang menerapkan AAUPPL untuk kajian berikut ini.

Para pihak dalam sengketa ini, Lindawati (Pemohon Kasasi, dahulu Penggugat/Pembanding) lawan Bupati Kepala Daerah Tingkat II Gianyar (Termohon Kasasi, dahulu Tergugat/Terbanding).

Secara singkat posisi kasus/duduk perkaranya sebagai berikut: Penggugat memiliki tanah seluas $600 \mathrm{~m}^{2}$ di Subak Basangamku NO. 129 dengan sertifikat hak milik No. 580. Berdasarkan akte jual beli maupun sertifikat, penggunaan tanah tersebut untuk bangunan/ perumahan. Di samping itu, berdasar Surat Keputusan
Kepala Desa Manukaya No. 593/57/Pem/ 1990 tertanggal 20 Maret 1990 menyebutkan tanah tersebut tidak terkena proyek jalur hijau.

Pada tanggal 17 Juli 1990 Penggugat telah mengajukan surat permohonan ijin prinsip kepada Gubernur Kepala Daerah Tingkat I Bali untuk mendirikan restoran rumah makan di atas tanah tersebut. Tetapi setelah sebulan ditunggu-tunggu belum ada jawaban, maka penggugat lalu mendirikan bangunan di atas tanah itu. Tiba bulan kemudian, keluar jawaban dari Gubernur yang isinya menolak permohonan Penggugat dengan alasan keamanan dari pura maupun istana yang ada di sekitarnya.

Terhadap perbuatan Penggugat mendirikan bangunan tersebut, Penggugat diajukan ke Pengadilan Negeri Gianyar dengan dakwaan melanggar pasal 216 ayat (1) KUH Perdata dan melanggar pasal 2 yis, pasal 3 huruf d, dan pasal 7 Perda No. 8 Tahun 1983, namun hingga sekarang perkara ini belum putus.

Kemudian Tergugat (Bupati Gianyar) dengan Surat Keputusannya No. 640/196/ PU/1991 tertanggal 5 Maret 1991 telah memerintahkan kepada Penggugat untuk membongkar bangunan tersebut sampai tanggal 15 Maret 1991. Karena Penggugat tidak mengindahkannya, disusuli Surat Keputusan No. 46 tahun 1991 tertanggal 16 Maret 1991 yang isinya Tergugat akan membongkar paksa bangunan itu pada tanggal 19 Maret 1991.

Terhadap gugata penggugat, Pengadilan Administrasi Ujung Pandang telah menjatuhkan putusan yang amarnya berbunyi:

- Menolak gugatan Penggugat untuk seluruhnya

- Menghukum Penggugat untuk membayar biaya perkara sebesar Rp. 
Penerapan AAUPPL Oleh Hakim Administrasi (Suatu Upaya ...); Jazim Hamidi

20.000 .

Pada Pengadilan Tingkat Banding, di antara amar putusannya berbunyi sebagai berikut:

- Memperbaiki putusan Pengadilan Administrasi Ujung Pandang No. 03/ Srt.G/TUN/1991/PTUN-U.Pdg/Acara cepat.

- Menolak gugatan Penggugat untuk seluruhnya.

Setelah putusan ini diberitahukan kepada kedua belah pihak, Penggugat/ embanding/sekarang Pemohon Kasasi mengajukan memori kasasi ke Mahkamah Agung RI disertai dengan keberatankeberatan.

Di antara pertimbangan hukum yang digunakan Hakim Mahkamah Agung dalam mengadili perkara ini adalah:

1) Keberatan-keberatan pemohon kasasi dapat dibenarkan, karena Pengadilan Tinggi telah salah menerapkan hukum dengan alasan di bawah ini.

2) Dalam pelaksanaan penerbitan perihal yang sama atau keadaan yang sama Pejabat Administrasi Negara harus melaksanakan Asas-asas Umum Pemerintahan Yang Layak yaitu asas persamaan dalam kasus yang sama haruslah diperlukan yang sama.

3) Berdasarkan keterangan saksi-saksi baik dari Penggugat maupun Tergugat dapat disimpulkan bahwa di jalur yang dilarang Perda No. 8 tahun 1983 untuk bangunan, kecuali bangunan milik Penggugat ada pula bangunanbangunan lain seperti: bangunan Pasraman para Sulinggih, bangunan milik Kepala Desa, bangunan Kantor Pengairan, yang setelah pembongkaran bangunan milik Penggugat, bangunan-bangunan tersebut masih saja ada.
4) Dalam hal perintah pembongkaran, pihak Tergugat tidak melaksanakan asas persamaan sebagai pemerintahan yang baik, maka walaupun pembongkaran sudah terlaksana, SK. Bupati No. 640/196/PU/1991 dan SK No. 46 Tahun 1991 dapat dibatalkan, karena hanya ditujukan kepada Penggugat saja, sedangkan pelanggar Perda No. 8 Tahun 1983 lainnya dibiarkan, sehingga perbuatan pembongkaran oleh Tergugat adalah suatu perbuatan melawan hukum oleh Pejabat (een onrechtmatige overheidsdaad).

Putusan Hakim Mahkamah Agung diantaranya:

- Mengabulkan permohonan kasasi Lindawati tersebut.

- Membatalkan Putusan Pengadilan Tinggi Administrasi Ujung Pandang No. 01/Bdg.G.TUN/1991/PT.TUN-U.Pdg. tertangal 17 Februari 1992 jo. Putusan Pengadilan Administrasi Ujung Pandang No.03/SRT.G/UN/ 991/P.TUN/ U.Pdg/Acara Cepat, tertanggal 30 mei 1991

Mengadili sendiri:

- Mengabulkan gugatan Penggugat untuk sebagian

- Menyatakan batal Surat Bupati Kepala Daerah Tingkat II Gianyar No. 640/196/ PU/1991 dan No. 46 Tahun 1991.

- Menolak gugatan Penggugat untuk selebihnya.

Komentar penulis terhadap Putusan Mahkamah Agung RI yang menerapkan AAUPPL di atas, diklasifikasikan dalam tiga kategori bahasan.

Pertama, berkaitan dengan penerapan AAUPPL oleh Hakim Mahkamah Agung sebagai "alat uji" terhadap keabsahan Keputusan Bupati Gianyar, yaitu: 
1. Secara teoretis, SK Bupati Gianyar di atas termasuk kategori Keputusan yang bersumber dari kewenangan bebas penguasa (yaitu asas nach freies ermessen atau dapat disebut vrij bestuur), terbukti SK. Bupati tersebut telah memerintahkan Penggugat untuk membongkar bangunannya dengan dalih untuk pembangunan (Proyek jalur hijau). Di samping itu, Bupati dengan SK susulannya memerintahkan "Bongkar paksa" dan bangunan milik tergugat akhirnya dibongkar. Tindakan semacam ini dalam illmu hukum administrasi disebut bestuursrwang. Padahal pelaksanaan bestuursdwang tidak cukup hanya berdasarkan aspek legalitas, melainkan harus tetap menghormati nilai-nilai kepatutan yang bersendikan keadilan. Terhadap jenis keputusan bebas (vrij beschikking) semacam inilah yang dapat diuji dengan AAUPPL.

2. Dalam pemeriksaan Hakim Kasasi ditemukan fakta yang tidak dipertimbangkan oleh Tergugat pada saat proses pembuatan dan pelaksanaan Surat Keputusan, yaitu ternyata selain bangunan milik Penggugat masih ada bangunan lainnya yang tidak ikut dibongkar, padahal bangunan-bangunan dimaksud sama-sama berada di kawasan terlarang (kawasan jalur hijau). Karena itu tepat, kalau Hakim Agung mengkualifisir bahwa tindakan Tergugat bertentangan dengan AAUPPL yaitu, asas persamaan.

3. Tindakan Tergugat mengeluarkan SK di atas, walaupun sudah didasarkan kepada Perda No. 8 tahun 1983 mengenai penataan jalur hijau, tetapi kenyataannya terbukti telah mengabaikan ketentuan hukum tidak tertulis yaitu AAUPPL (asas persamaan). Hemat penulis, tindakan semacam ini dapat dikategorikan perbuatan melawan hukum (een onrechtmatige overheidadaad).

4. Sudah seharusnya SK. Bupati tersebut dibatalkan, karena nyata-nyata bertentangan dengan pasal 53 ayat 2 (khususnya butir a dan b) UU No. 5 tahun 1986.

Kedua, berkaitan dengan mekanisme (proses) penerapan AAUPPL oleh Hakim Agung. Hemat penulis, Hakim Agung dalam mengikuti dengan baik JUKLAK No. 052/ Td.TUN/III/1992. Terbukti pada saat Hakim mempertimbangkan adanya salah satu asas dari AAUPPL yang dilanggar oleh Tergugat, hakim tidak mencantolkan pertimbangannya pada ketentuan Pasal 53 ayat (2) UU No. 5 Tahun 1986. Di samping itu, asas persamaan yang dikualifisir telah dilanggar tersebut belum dimasukkan pada ketentutan Pasal 53 ayat (2) butir b (asas penyalahgunaan wewenang/detournement de pouvoir) atau butir c (asas bertindak tidak sewenang-wenang/willlekeur). Padahal asas persamaan dapat dimasukkan pada rumusan ketentuan butir $b$ tersebut.

Ketiga, dalam konteks kasus di atas, temuan penulis menunjukkan bahwa indikator-indikator asas persamaan sebagai telah dilanggar, apabila:

- Dalam kasus dan keadaan yang sama, harus diperlakukan dengan sama pula.

- Dalam hal-hal tertentu, tindakan paksa Administrasi Negara (bestuursdwang) tidak boleh mengabaikan nilai-nilai kepatutan (AAUPPL), dalam hal ini terelaborasi dalam penilaian, sikap, dan perlakuan Tergugat yang subyektif (menafikan aspek persamaan)

- Pelaskanaan asas persamaan, perlu didasarkan kepada peraturan kebijakan

- Pelaksanaan asas persamaan, harus mencerminkan prinsip-prinsip keadilan. 
Penerapan AAUPPL Oleh Hakim Administrasi (Suatu Upaya ...); Jazim Hamidi

\section{Penutup}

Simpulan yang dapat penulis kemukakan adalah: Hakim Administrasi dapat menerapkan AAUPPL untuk menguji keabsahan Keputusan Administrasi Negara dengan jalan menghubungkan kaidah hukum substantif melalui penalaran deduktif. Dasar kewenangannya dapat ditemukan pada Pasal 14 jo. Pasal 27 UU No. 14 Tahun 1970 , Pasal 53 ayat (2) UU No. 5 Tahun 1986, dan Juklak Ketua Muda Mahkamah Agung Lingkungan PTUN No. 052/Td.TUN/III?1992.

Pada saat Hakim Administrasi menerapkan AAUPPL, terdapat dua tolok ukur yang dapat digunakan untuk mengkualifikasi suatu Keputusan Administrasi Negara bertentangan dengan AAUPPL atau tidak, yaitu berupa norma hukum tertulis (sebagaimana diatur dalam pasal 53 ayat (2) UU No. 5 Than 1986) dan kaidah hukum tidak tertulis (berupa AAUPPL).

AAUPPL merupakan salah satu alat kontrol yang efektif untuk menguji kebijakan (Keputusan) Administrasi Negara yang tidak terjangkau oleh ketentuan hukum tertulis. Dengan demikian akan dapat terminimalisir adanya kebijakan Administrasi Negara yang "kebal hukum", dimana belakangan ini mulai terasakan. Hemat penulis, upaya penerapan AAUPPL semacam ini, dapat mengimplementasikan pembentukan clean and stable government yang kita cita-citakan bersama.

\section{Daftar Pustaka}

Adnan Buyung Nasution, 1995, The Aspiration for Constituantional Government in Indonesia: A Socio-Legal Study of the Indonesian Konstituante 1956 1959, Terjemahan Sylvia Tiwon, Aspirasi Pemerintahan Konstitusional di Indonesia: Studi Sosio-Legal atas Konstituante 1956-1959, cet. Pertama, Jakarta:Grafiti Press.

A. Hamid S. Attamimi,1990. Peranan Keputusan Presiden Republik Indonesia dalam Penyelenggaraan Pemerintahan Negara (Suatu Studi Analisis Mengenai Keputusan Presiden yang Berfungsi Pengaturan dalam Kurun Waktu Pelita I - Pelita IV), Disertasi,Jakarta: Fakultas Pascasarjana, Universitas Indonesia.

Anonim, 1993. Himpunan Putusan Sengketa Tata Usaha Negara, cet. Pertama, Jakarta:Mahkamah Agung RI.

, 1994. Himpunan Putusan Sengketa Tata Usaha Negara, cet. Pertama,Jakarta Mahkamah Agung RI.

,1994. Himpunan PERMA, SEMA, dan JUKLAK tentang Peradilan Tata Usaha Negara, Jakarta:Mahkamah Agung RI.

Ateng Syafrudin,1982. Memantapkan Pemerintahan Yang Bersih, Kuat dan Berwibawa, cet. Pertama, Bandung: Tarsito.

1994. Kepala Daerah, cet. Pertama,Bandung: Citra Aditya Bakti.

Bachsan Mustafa,1990. Pokok-pokok Hukum Administrasi Negara, cet. Kelima, Bandung:Alumni.

Bagir Manan,1995. Kekuasaan Kehakiman Republik Indonesia, cet. Pertama, Bandung:Pusat Penerbitan UNISBA. 
UNISIA, Vol. XXX No. 66 Desember 2007

Indroharto, 1985.Asas-asas Umum Pemerintahan Yang Baik,Jakarta: Mahkamah Agung.

Kuntjoro Purbopranoto,1985. Beberapa Catatan Hukum Tata Pemerintahan dan Peradilan Administrasi Negara, cet. Keempat, Bandung:Alumni.

Moh. Koesnoe, Perumusan dan Pembinaan Cita Hukum dan Asas-asas Hukum Nasional Ditinjau dari Hukum Adat, Dimuat dalam Varia Peradilan tahun X No. 120, September 1995.

Mochtar Kusumaatmadja, Pemantapan Cita Hukum dan Asas-ass Hukum Nasional di Masa Kini dan Masa yang Akan Datang, Makalah disajikan dalam Seminar tentang "Temu Kenal Cita Hukum dan Penerapan Asasasas Hukum Nasional" Oleh BPHNDEPKEH, Jakarta, 22 -24 Mei 1995.

Otje Salman,1986. Ikhtiar Filsafat Hukum, cet. Pertama,Bandung: Armico.

Paulus Effendie Lotulung (Peny), 1994. Himpunan Masalah Asas-asas Umum Pemerintahan Yang Baik, cet. Pertama, Bandung:Citra Aditya Bakti.
Paul Scholten,1993. Handlaiding tot den Beofening van het Nederlandsh Bugerlijk Recht: Algemeen dell, diterjemahkan Siti Soemantri Hartono, Penuntun Dalam Mempelajari Hukum Perdata Belanda Bagian Umum, cet. Kedua, Yogyakarta:Gajahmada University Press.

Philipus M. Hadjon, Pengkajian Ilmu Hukum Dogmatik (Normatif), Majalah Yuridika, No. 6 Tahun IX, November Desember, 1994

Sjachran Basah, 1989. Eksistensi dan Tolok Ukur Peradilan Administrasi di Indonesia, cet. Kedua,Bandung: Alumni.

Sri Soemantri M.,1992. Bunga Rampai Hukum Tata Negara Indonesia, cet. Pertama, Bandung:Alumni.

Sudikno Mertokusumo dan A. Pitlo,1993. Bab-bab Tentang Penemuan Hukum, cet. Pertama, Bandung:Citra Aditya Bakti.

Veld, J. In't dan N.S.J. Koemen,1985. Beginselen van Behoorlijk Bestuur, W.E.J. Tjeenk Willink, Zwole. 